\title{
Impact of Soil and Water Conservation Practices in Central North Plateau Zone of Odisha
}

\section{SUVASHREE RANJITA PRUSTY*, SARBA NARAYAN MISHRA and SUDHAKAR TRIPATHY}

\author{
Department of Agricultural Economics, College of Agriculture, \\ Orissa University of Agriculture and Technology, \\ Bhubaneswar, Odisha, 751003, India. \\ *Corresponding author Email: suvashreeprusty@gmail.com
}

http://dx.doi.org/10.12944/CWE.11.1.19

(Received: January 28, 2016; Accepted: February 25, 2016)

\begin{abstract}
The present study was undertaken in two village Tentuli and Talachampei of Keonjhar district of Odisha which come under the central north plateau zone. This zone is characterized by hilly upland area with reduced moisture holding capacity. Therefore an attempt has been made to study the various soil and water conservation practices on cost and return of crop production, to identify factors affecting yield of crops with different treatments and to study the farmer's perception of conservation agriculture production system. For this study 18 marginal and 2 small farmers were selected by employing multistage stratified random sampling method. Five different trials or treatments namely $T_{1}$ (Traditional practice), $T_{2}$ (Conventional tillage with HYV maize), $T_{3}$ (Conventional tillage with maize-cowpea intercropping), $T_{4}$ (Minimum tillage with maize as sole crop), $T_{5}$ (Minimum tillage with maize cowpea intercropping) were conducted in the field. It was observed that $T_{5}$ gave highest net return (Rs.57352.41/ha) followed by $\mathrm{T}_{2}$ (Rs.54426.71/ha), $\mathrm{T}_{3}$ (Rs.47376.12/ha), $\mathrm{T}_{1}$ (Rs.46376.09/ ha). The lowest income of Rs.14359.9/ha was observed in case of $T_{1}$. Fertilizer with minimum tillage and intercropping influenced gross income positively and significantly through soil and water conservation practice. High yielding variety and line sowing were two most influencing factors on crop production. Most profitable treatment according to farmer's perception was $T_{5}$. Lack of irrigation facilities was important constraint in cultivation practices. Farmers should be trained for adoption of soil and water conservation practices like minimum tillage, residue mulching, inter-cropping, crop rotation, line sowing and use of HYV seeds for sustainable crop production.
\end{abstract}

Key words: "upland", "conservation", "trial", "sustainable".

\section{INTRODUCTION}

Global agriculture is facing numerous challenges like adversely affected food and nutritional security. According to Teklu (2006), land is one of the major conventional inputs that limit agricultural production because it is major source of farming. Intensive agriculture and extreme use of external inputs are leading to degradation of soil water and genetic resources. Estimates reveal that annual loss of soil translates into US $\$ 400$ billion per year, about 10 million hectare of good quality land is lost annually for agricultural practices and 1.5 billion people depends directly degraded land (FAO,2012). The per capita landholding is diminishing year after year. For example, the average landholding size was diminished from 1.4 to under a hectare during the 1977-2002 (Nagayets, 2005).

India with share of $2.3 \%$ of world's land area with $11.5 \%$ of arable lands and $4.2 \%$ water resources supports $16.9 \%$ of world's population and $20.3 \%$ (GOI, 2O12) of economically active population depending on agriculture. With the net sown area hovering around 140 million hectare with declining land-man ratio, increasing number of operational 
holdings, reducing agro bio-diversity, the country is faced with huge challenges to meet the demand of food and feed of increasing human and livestock population.

Indian agriculture has entered a new phase i.e. Post green revolution era. This era focused on enhancing productivity of selected food grains and other crops. The new challenges demand the efficient resource use and conservation to ensure gains in production and productivity in order to meet the emerging needs. Issues of conservation is important because resources degradation and need to reduce production costs, increase profitability for competitive agriculture. The conventional agriculture practice through intensive agricultural practices leads to good production but causes natural resource degradation. Hence, sustainable agriculture is the ultimate solution to maintain natural equilibrium and encourage natural regenerative process.

Three key principles of Conservation agriculture are minimal soil disturbance, retaining of permanent soil organic cover and diversified crop rotation. It permits management of soils for agricultural production without excessively disturbing the soil while protecting it from the process that contribute to degradation e.g. erosion, compaction, aggregate breakdown, loss in organic matter, leaching of nutrient etc. in the conventional systems, while soil tillage is necessary to produce crop. Intensive tillage leads to gradual decline in soil organic matter through accelerated oxidation and burning of crop residues causing pollution, green house gases emission and loss of plant nutrient.

Since many countries for years have been faced with a serious crisis due to shortage of water resources on one hand and on other hand due to population growth and economic and social development, it can be said that water problems in the future would be more and more and water would be undoubtedly an important issue (Kim and Najafi 2005). The proper water management in this sector is essential and plays a critical role on the sustainable development of agriculture (Keshavarz and Heydari, 2004). The aim of the effective management of agricultural water is to increase economic performance with reduced consumption of water and energy (Pandy et al, 2000; Panda et al, 2004).

Keonjhar district of Odisha mostly depends on subsistence agriculture. The soil is characterized by scanty moisture holding capacitated degraded land and soil moisture by run-off water from nearby hills. The major soil of the district include red lateritic and the zone is mostly upland, some part comprises of medium land. Hilly region of the area are mostly highlands where study has been conducted. Rain fed mono-cropping are mostly practiced, so production and productivity are both declining. Major field crops grown there are rice, maize, pulses like black gram, horse gram, green gram, cow pea and oil seeds like Niger. Through invention of new practices like conservation agriculture system, crop productive capacity can be enhanced. Hence, the present study had been made with main objectives like

a) To study the various soil and water conservation practices on cost and return of crop production.

b) To identify factors affecting yield of crops with different treatments.

c) To study the of farmer's perception conservation agriculture production system.

\section{MATERIALS AND METHODS}

A multistage stratified random sampling method was employed for selection of two villages Tentuli and Talachampei of Keonjjhar district, where as the district was selected purposefully in the year 2013-14. Eighteen marginal and two small farmers were selected randomly by their farm size.

\section{The trial}

Twenty farmers have been allocated specified research area the patches of area were split into five equal parts on which the treatments conducted.

\section{Treatment $1\left(T_{1}\right)$}

Broadcasting indigenous seeds + tillage (no chemicals and fertilizer)

\section{Treatment $2\left(\mathrm{~T}_{2}\right)$}

Conventional tillage+ HYV (maize variety-

Nilesh) +required dose of fertilizer 
Treatment $3\left(\mathrm{~T}_{3}\right)$

Conventional tillage+ maize (variety-Nilesh), cowpea (variety-Hariyali bush) intercropping+ required dose of fertilizer + herbicide

\section{Treatment $4\left(\mathrm{~T}_{4}\right)$}

Conservation tillage (light tillage) + HYV (maize variety-Nilesh) +required dose of fertilizer

\section{Treatment $5\left(\mathrm{~T}_{5}\right)$}

Conservation tillage (light tillage) + HYV (maize variety-Nilesh) cowpea (variety-Hariyali bush) intercropping +required dose of fertilizer.

\section{Statistical tools used}

A multiple regression analysis was carried out to find out the effects of factors like fertilizer, labour and soil, water conservation practice.

\section{Regression analysis}

$\mathrm{Y}=\mathrm{a}+\hat{\mathrm{a}}_{1} \mathrm{X}_{1}+\hat{\mathrm{a}}_{2} \mathrm{X}_{2}+\mathrm{D}+\mathrm{ei}$

Where, $Y=$ Gross return per hectare

$X_{1}$ per hectare expenditure on fertilizer

$\mathrm{X}_{2}=$ per hectare expenditure on labour

$\mathrm{D}=$ Dummy variable which take

1 for minimum tillage/maize cow pea inter crop
0 for conventional tillage/maize as sole crop

ei $=$ stochastic error term

$\hat{a}_{0}$ is regression coefficient of dependent variable

$\hat{a}_{1}, \hat{a}_{2}$ are regression coefficient of independent variable

a test of significance of regression coefficient was examined by ' $\mathrm{t}$ ' test.

$$
\mathrm{t}=\frac{\mathrm{bi}}{\mathrm{S} . \mathrm{E}(\mathrm{bi})}
$$

Kendall's coefficient of concordance

It was used to rank correlation coefficient for farmer's perception

$\mathrm{W}=\mathrm{s} /\left\{1 / 12 \mathrm{k}^{2}\left(\mathrm{~N}^{2}-\mathrm{N}\right)\right\}$

Where,

$\mathrm{S}=\Sigma\left(\mathrm{R}_{\mathrm{i}}-\mathrm{R}_{\mathrm{j}}\right)$

$\mathrm{K}=$ no. of sets of ranking

$\mathrm{N}=$ number of object ranked

$1 / 12 k^{2}\left(N^{2}-N\right)=$ maximum possible sum of squared deviations

\section{Garrett ranking}

Constraint perceived by the farmers were analyzed using Garrett ranking technique

Per cent position $=\frac{100\left(R_{i j}-0.50\right)}{N_{j}}$

Table 1: Composition of variable cost of different treatment

\begin{tabular}{llccccc}
\hline SI.No & Particulars(Rs/Ha) & \multicolumn{5}{c}{ Treatments } \\
& & $\mathbf{T}_{\mathbf{1}}$ & $\mathbf{T}_{\mathbf{2}}$ & $\mathbf{T}_{\mathbf{3}}$ & $\mathbf{T}_{\mathbf{4}}$ & $\mathbf{T}_{\mathbf{5}}$ \\
\hline 1 & Family labour & 3098.23 & 3197.55 & 6117.67 & 2873.79 & 5687.67 \\
& & $(63.84)$ & $(54.45)$ & $(57.25)$ & $(55.09)$ & $(57.66)$ \\
2 & Bullock labour & 525 & 525 & 525 & 175 & 175 \\
& & $(10.81)$ & $(80.94)$ & $(04.91)$ & $(03.35)$ & $(01.77)$ \\
3 & Seeds & 535.1 & 303.5 & 1395.05 & 303.05 & 250 \\
& & $(11.02)$ & $(05.15)$ & $(13.05)$ & $(05.80)$ & $(02.53)$ \\
4 & Manure & 375 & 450 & 350 & 450 & 1395.05 \\
& & $(07.72)$ & $(07.66)$ & $(03.27)$ & $(08.62)$ & $(14.14)$ \\
5 & Fertilizer & 0 & 1104.22 & 1602.14 & 1104.22 & 350 \\
& & & $(18.80)$ & $(14.99)$ & $(21.16)$ & $(03.54)$ \\
6 & Plant protection measure & 0 & 0 & 188.82 & 0 & 188.85 \\
& & & & $(01.76)$ & & $(01.91)$ \\
7 & Interest on working capita & 257.18 & 292.58 & 506.18 & 309.97 & 465.13 \\
& & $(05.29)$ & $(04.98)$ & $(04.74)$ & $(05.94)$ & $(04.62)$ \\
8 & Total variable cost & 4852.86 & 5872.41 & 10684.89 & 5216.03 & 9863.84 \\
& & $(100.00)$ & $(100.00)$ & $(100.00)$ & $(100.00)$ & $(100.00)$ \\
\hline
\end{tabular}

(Figure in parentheses indicate percentage) 
Where, $R_{i j}$ is the rank given for $i_{\text {th }}$ items by $\mathrm{j}_{\mathrm{th}}$ individual, $\mathrm{N}_{\mathrm{j}}$ is the number of items ranked by the $\mathrm{j}^{\text {th }}$ individual

The per cent position of each rank is converted into scores by referring the table given by Garrett and Woodworth (1969). Then for each factor, the scores of individual respondents are added together and divided by the number of respondent for whom scores are added. The mean scores for all the factors are ranked by arranging in descending order.

\section{RESULTS}

Considering the seriousness of upland soil problems like rapid rain water runoff and erosion which reduces their productive capacity and agronomic potential, adoption of cost effective moisture retention and conservation technologies were carried out by different treatments on trial basis .These were given in tabular form.

\section{DISCUSSION}

Income per hectare is an important parameter on the part of the farmer to consider the adoption of the technique; the profit from variable cost is taken into consideration. The variable costs of different treatment in the study area were shown in Table-1. It was found that highest variable cost of $\mathrm{T}_{3}(10684.89 / \mathrm{ha})$ followed by $\mathrm{T}_{5}(9863.84)$ and lowest was in $T_{1}$ (4852.86). It was also found that highest amount of variable cost due to family labour in all the five treatments that contribute near around fifty percent of total variable cost in all the treatments.

For every production process cost benefit ratio is crucial in order to find out whether that practice is beneficial or not. It was found in Table 2 that net income was highest in $T_{5}(60177.95 / h a)$ followed by $T_{2}$ (58157.93/ha) and lowest was in $T_{1}$ (15893.61/ha). Yield was highest in $T_{5}$ followed by $T_{2}$ and lowest was in $T_{1}$

Table 2: Average yield, gross income and net return of the villages of study area

\begin{tabular}{llccccc}
\hline Benefit & Particulars(Rs/ha) & $\mathbf{T}_{\mathbf{1}}$ & $\mathbf{T}_{\mathbf{2}}$ & $\mathbf{T}_{\mathbf{3}}$ & $\mathbf{T}_{\mathbf{4}}$ & $\mathbf{T}_{\mathbf{5}}$ \\
\hline Average yield & Cobs/ha & 13831 & 33735 & 30920 & 19157 & 34924 \\
& Cow pea(kg/ha) & & & 855.1 & & 739.45 \\
Gross income & Rs/ha & 20746.47 & 64030.34 & 31353.25 & 54814 & 70480.8 \\
Net income & Rs/ha & 15893.61 & 58157.93 & 50668.36 & 49597.96 & 60177.95 \\
\hline
\end{tabular}

Table 3 a: Regression analysis Taking tillage as dummy variable

\begin{tabular}{|c|c|c|c|}
\hline $\begin{array}{l}\text { SI. } \\
\text { No }\end{array}$ & Particulars & $\begin{array}{l}\text { Regression } \\
\text { Coefficient }\end{array}$ & $\mathbf{R}^{2}$ \\
\hline i & Constant & $\begin{array}{l}42573.11^{\star *} \\
(3425.72)\end{array}$ & 0.86 \\
\hline ii & Labour & $\begin{array}{l}1.65 \\
(10.29)\end{array}$ & \\
\hline iii & Fertilizer & $\begin{array}{l}154.91^{\star *} \\
(30.005)\end{array}$ & \\
\hline iv & Tillage & $\begin{array}{l}6596^{\star \star} \\
(1867.92)\end{array}$ & \\
\hline
\end{tabular}

${ }^{*}$ significant at $1 \%$ level of significance
Table 3 b: Regression analysis taking intercropping as dummy variable

\begin{tabular}{|c|c|c|c|}
\hline $\begin{array}{l}\text { SI. } \\
\text { No }\end{array}$ & Particulars & $\begin{array}{l}\text { Regression } \\
\text { Coefficient }\end{array}$ & $\mathbf{R}^{2}$ \\
\hline i & Constant & $\begin{array}{l}46949.75^{\star *} \\
(2248.78)\end{array}$ & 0.83 \\
\hline ii & Labour & $\begin{array}{l}3.48 \\
(13.17)\end{array}$ & \\
\hline iii & Fertilizer & $\begin{array}{l}148.68^{\star \star} \\
(35.04)\end{array}$ & \\
\hline iv & intercropping & $\begin{array}{l}2056.72^{\star \star} \\
(306.61)\end{array}$ & \\
\hline
\end{tabular}

*significant at $1 \%$ level of significance 
Table 4 a: Ranking of conservation agriculture practice by farmers preference

\begin{tabular}{llll}
\hline SI. No & Factors & Mean value score & Garrett's rank \\
\hline 1 & HYV variety & 83 & 1 \\
2 & Line sowing & 75.20 & 2 \\
3 & Maize-cowpea intercropping & 69.40 & 3 \\
4 & Minimum tillage & 63.30 & 4 \\
5 & Residue mulching & 56.10 & 5 \\
\hline
\end{tabular}

Table 4 a: Ranking of conservation agriculture practice by farmers preference

\begin{tabular}{llll}
\hline SI. No & Factors & Mean value score & Garrett's rank \\
\hline 1 & T1 & 60.40 & 5 \\
2 & T2 & 75.70 & 2 \\
3 & T3 & 68.20 & 3 \\
4 & T4 & 67.70 & 4 \\
5 & T5 & 81 & 1 \\
\hline
\end{tabular}

The factor which affects the yield positively was shown in the Table 3. It was found in Table $3(a)$ that fertilizer and tillage affects the yield of crop positively and significantly in all treatments where applied in case of tillage taken as dummy variable. In Table 3(b) revealed that treatments where intercropping is taken as dummy variable fertilizer and intercropping effects crop yield positively and significantly.

Farmer's preference about the factors which affects the yield and profit were depicted in Table 4. It was found that farmers prefer mostly HYV for more yields followed by line sowing that was shown in table 4(a). When treatments were concerned for more profitability, farmer's perception was shown in table 4(b). It was scored highest for $\mathrm{T}_{5}$ and lowest for $\mathrm{T}_{1}$ as per farmer's preference

\section{CONCLUSION}

The cost analysis reveals that the total variable costs of all treatments not vary much except for the intercropping treatments. But average yield of maize varies significantly among all these treatments. In both studies of two villages, the farmers practice the average yield of maize as sole crop is 13343 cobs per hectare followed by minimum tillage treatment with maize as sole crop. It showed that the average yield of minimum tillage treatment is significantly higher than farmer's traditional practice. Highest net return was found in $\mathrm{T}_{5}(60177.95 / \mathrm{ha})$ and lowest yield was in $T_{1}(15893.61 / h a)$ where conventional method of crop cultivation was practiced. This showed that tillage, intercropping as conservation agriculture practices coupled with high yielding variety seeds result high yields and returns in the study area. While conducting ranking farmers were not agreement with each other or they were all independent in their decision because they had their own perception about intervention practice, but overall perception survey revealed that yield and profit were two most determining factors, HYV seeds and line sowing influences most profitably to conservation practice and $T_{5}$ treatment was most profitable. According to farmer's knowledge and experience irrigation was most vicious constraints in cultivation practices. Farmers should be trained for adoption of soil and water conservation practices like minimum tillage, residue mulching, inter-cropping, crop rotation, line sowing and use of high yielding variety seeds for sustainable crop production. 


\section{REFERENCES}

1. Directorate of Agriculture and food production, Govt. of India, India Agriculture statistics, (2012)

2. FAO, FAO Statistical Database, Online, http:// apps.fao.org (2012)

3. Keshavarz, A., \& Heydari, N., Reviewing the Extravagance and Waste Water Resources in the Production and Consumption of Agricultural Water Development. Proceedings of the First National Conference of Agricultural Wastes, Seed and Plant Improvement Institute, Faculty of Agriculture, Tarbiat Modares University (2004)

4. Kim, H., \& Najafi, K., Characterization of Low-Temperature Wafer Bonding Using Thin Film Parylene," IEEE/ASME Journal of Micro electro-mechanical Systems ,14(6): 13471355(2005)

5. Panda, R. K., Behera, S. K., \& Kashyap, P. S., Effective Management of Irrigation Water for
Maize under Stressed Conditions. Agricultural Water Management, 66(3): 181-203(2004)

6. Pandy, R. K., Maranville, J. W., \&Admou, A., Deficit Irrigation and Nitrogen Effects on Maize in a Sahelian Environment: I. Grain Yield and Yield Components. Agricultural Water Management, 46(1): 1-13(2000)

7. Nagayets, O., Small Farms: Current Status and Key Trends. Prepared for the Future of Small Farms Research Workshop. Wyne College, June 26-29, 2005. The 2020 Vision for Food, Agriculture, and the Environment, Information Brief. International Food Policy Research Institute (IFPRI).Washington, D.C, USA, 365-367(2005)

8. Teklu, T., Land Scarcity, Tenure Change, and Public Policy in the African Case of Ethiopia: Evidence on Efficacy and Unmet Demands for Land Right (2006) 